\title{
Deportation Decisions Judicial Decision-Making in an American Immigration Court
}

\author{
Asad L. Asad \\ Center for the Study of Inequality Department of Sociology \\ Cornell University Stanford University
}

Correspondence: Asad L. Asad, Center for the Study of Inequality, Cornell University; Department of Sociology, Stanford University; E-mail: asad.asad@cornell.edu.

Forthcoming in American Behavioral Scientist

\begin{abstract}
Drawing on ethnographic observations and informal conversations with judges in Dallas Immigration Court, as well as archival documents, this article describes two approaches through which judges in this setting justify their decisions during removal proceedings. The "scripted approach," used to effect the routine removal of noncitizens in most of the completed cases observed, entails judges' recitation of well-rehearsed narratives regarding the limited legal rights and remedies available to noncitizens. The "extemporaneous approach" involves judges moving beyond their scripts and deliberating in greater depth about noncitizens' cases. In doing so, judges' personal attitudes, biases, and motivations are often revealed as they articulate their desire to circumvent the removal process for noncitizens they view as "deserving" of relief - but for whom only temporary relief from removal is often available given judges' interpretations of immigration law. Although judges recognize that this temporary relief may allow some noncitizens to remain in the United States indefinitely, incomplete protection from removal can leave noncitizens in a precarious legal status and jeopardize these individuals' future opportunities for legalization. These findings support a conceptualization of immigration judges as street-level bureaucrats, or frontline workers who interpret the law-sometimes unevenly-in order to enforce government policy while interfacing with the individuals subject to said policy, and amplify the social control capacity of the federal immigration regime.
\end{abstract}

\section{KEYWORDS}

immigration law; removal or deportation; immigration judges; decision-making; street-level bureaucrats; ethnography

\section{ACKNOWLEDGEMENTS}

I acknowledge financial support from the National Science Foundation Graduate Research Fellowship (DGE1144152). I thank the anonymous reviewers, Monica Bell, Matthew Clair, Filiz Garip, Shannon Gleeson, Matthew Hall, Ben Rissing, Emily Ryo, and participants at Cornell University's Criminalizing Immigrants Conference for helpful comments on previous versions of this article. Students in the "Law and Sociology" course at Yale Law School also provided valuable comments. Any errors are mine. 


\section{INTRODUCTION}

Removal, or deportation, is a primary component of the contemporary federal immigration regime in the United States. Of the 7.4 million removals logged between 1892 and 2015, half occurred in the decade since $2005 .{ }^{1}$ Deportation's recent rise as a tool to regulate noncitizens owes to a series of federal reforms since the late 1980s that have imported practices from criminal law and justice into immigration law and enforcement, a phenomenon known as "crimmigration" (Stumpf 2006). A growing literature has depicted the far-reaching consequences of removal for noncitizens, their U.S.-citizen family members and communities, and the countries to which they are deported (see, e.g., Asad and Clair 2018; Dingeman-Cerda 2017; Hagan et al. 2008; Menjívar et al. 2016).

Almost 300 sitting immigration judges in 58 immigration courts nationwide process about onethird of all removals ordered each year. In fiscal year (FY) 2011, 265 immigration judges decided 220,048 cases; 57 percent concluded with a removal order (Benson and Wheeler 2012: 127). An emerging literature describes the structural and bureaucratic constraints to immigration judges' decision-making that likely contribute to high removal rates, including an unprecedented backlog of complex cases demanding speedy adjudication (Benson and Wheeler 2012; Lustig et al. 2008). These constraints have become more salient during the Trump administration, with immigration judges under pressure to clear a minimum of 700 cases per year. ${ }^{2}$ In research based primarily on administrative and survey data (e.g., Keith et al. 2013; Rottman et al. 2009; Ryo 2016; Schrag et al. 2009), scholars suggest that immigration judges may rely on their own personal attitudes, biases, or motivations - using noncitizens' individual case characteristics as proxies for how "American" (Mendelson 2010) or "dangerous" (Ryo forthcoming-a) they perceive a noncitizen to be, for example - to simplify the decision task. However, little research has examined in real time how judges justify their decisions during removal proceedings.

This article draws on ethnographic observations of and informal conversations with immigration judges in Dallas Immigration Court, as well as archival documents, to describe how judges in this setting justify their decisions. Two approaches emerged through inductive analysis of these data. The "scripted approach" entails judges' recitation of well-rehearsed narratives regarding the limited legal rights and remedies available to most noncitizens. Judges used this scripted approach to explain the routine removal of noncitizens in most of the completed cases I witnessed. When the particulars of a case deviated from the routine, the judges I observed relied on an "extemporaneous approach" in which they moved beyond their scripts and deliberated in greater depth about the cases before them. In doing so, judges' personal attitudes, biases, and motivations were often revealed as they articulated their desire to circumvent the removal process for noncitizens they viewed as "deserving" of relief - but for whom full relief from removal was often unavailable given judges' interpretations of immigration law. These findings support a framework of judicial decision-making in immigration court that conceptualizes judges as street-level bureaucrats, or frontline workers who interpret the law-sometimes unevenly-in order to enforce government policy while interfacing with the individuals subject to said policy.

\footnotetext{
${ }^{1}$ Source: Department of Homeland Security. 2016. "Table 39: Aliens Removed or Returned: Fiscal Years 1892 to 2015."

${ }^{2}$ Rose, Joel. 2018. “Justice Department Rolls Out Quotas for Immigration Judges.” National Public Radio. April 3. $<$ https://n.pr/2GEZp4Q>. Accessed online June 15, 2018.
} 
This study makes several contributions to research on the federal immigration regime.

Methodologically, the ethnography serves as a rare qualitative complement to the growing body of quantitative analyses of immigration court, illuminating some of the hard-to-quantify social processes underlying judicial decision-making in removal proceedings. Empirically, I document how immigration judges, key actors in the deportation process, justify their decisions in one immigration court. Theoretically, conceptualizing immigration judges as street-level bureaucrats foregrounds their role as complex, creative actors situated within structural and bureaucratic contexts that enable or constrain their discretionary authority. Even when judges offer some noncitizens temporary relief from removal, incomplete protection from removal can leave noncitizens in a precarious legal status and jeopardize their future opportunities for legalization. The study thus amplifies the social control capacity of the federal immigration regime.

\section{REMOVING NONCITIZENS FROM THE UNITED STATES}

\section{Expanding Federal Immigration Enforcement, Limiting Judicial Discretion}

Deportation emerged as a primary mechanism for regulating "legal" and "illegal" noncitizens alike beginning in the 1980s (Asad 2017; see García Hernández 2014 for a comprehensive review). Policy changes imported tools from criminal law and justice into immigration law and enforcement (Stumpf 2006), limiting judicial discretion and noncitizens' due process rights along the way (Kanstroom 2007: 122-4; see also Chacón 2010). The Immigration and Nationality Act (INA) of 1988 represents a first step in this convergence by rendering noncitizens convicted of "aggravated felonies"- here, murder and drug or firearms trafficking_-deportable. In 1990, amendments to the INA eliminated the long-standing authority of criminal judges to advise against the deportation of a noncitizen convicted of a crime (see Fine 1997).

Four years later, Congress authorized the U.S. Attorney General to deport without judicial review any noncitizen convicted of an aggravated felony who was not a legal permanent resident and who appeared to be ineligible for relief (Kanstroom 2007). In 1996, the Anti-Terrorism and Effective Death Penalty Act broadened the category of aggravated felonies to encompass many nonviolent crimes for which the term of imprisonment is at least one year (see Golash-Boza 2013: 206). This widening deportation dragnet coincided with an intensification of enforcement efforts through the Illegal Immigration Reform and Immigrant Responsibility Act (IIRIRA), which allowed for the removal of noncitizens ever convicted of an aggravated felony, the mandatory detention of certain classes of noncitizens, and the ongoing cooperation between federal immigration authorities and state and local law enforcement. Figure 1 depicts how, in part due to these changes, the number of removals from the country proliferated in the 1990s.

[Figure 1 about here.]

Given that these changes facilitated removal absent judicial review, only about one-third of contemporary removals stem from the order of an immigration judge overseeing removal proceedings in immigration court (see American Immigration Council 2014; see also Benson and 
Wheeler 2012: pp. 9-13 for a helpful summary). ${ }^{3}$ It is these proceedings - and judges' decisionmaking within them - that are the focus of this article.

\section{Judicial Decision-Making in U.S. Immigration Courts}

Immigration judges' role in removal proceedings is outlined in the INA ( $§ 240)$. They derive no authority from Article III of the U.S. Constitution that establishes the federal judiciary. Rather, immigration judges are career lawyers whom the U.S. Attorney General has appointed to serve as administrative judges within the Department of Justice. They preside over proceedings between a Department of Homeland Security (DHS) prosecutor, who represents the government, and a noncitizen, who lacks a constitutional right to court-provided counsel (see Ryo

forthcoming-b: pp. 4-5). I outline more fully the different stages of removal proceedings below, but, broadly, they include: a judge's initial determination of whether there are valid grounds for removing a noncitizen; if so, whether the noncitizen will seek relief; and if so, whether the judge will grant relief or order the noncitizen removed (see Ryo 2016: pp. 120-1).

Despite judges working under the same federal immigration regime, scholars note variation in removal outcomes between (see Benson and Wheeler 2012: 125-7) and within (e.g., Keith et al. 2013; Schrag et al. 2009) court jurisdictions. ${ }^{4}$ For example, 66 percent of completed cases in Dallas Immigration Court, and 71 percent of completed cases in Houston Immigration Court, ended with a removal order in FY2015. The rate in immigration courts in Los Angeles, San Francisco, and San Diego was 24 percent, 29 percent, and 32 percent, respectively.

[Figure 2 about here.]

One potential source of this variation between courts is structural. Although not Article III judges, immigration judges work in courts that fall within one of eleven federal circuit court districts (see Figure 2). Immigration judges are bound by various standards set forth in federal law - including statutes, legal precedent, and court rules - that are particular to each circuit. Considered alongside the nonrandom distribution of noncitizens' cases (Moinester 2018) and place-based variation in noncitizens' access to legal resources (Eagly and Shafer 2015), noncitizens in similar legal situations processed through immigration courts in different federal circuits can have dissimilar removal outcomes (Moinester 2018).

Another potential source of this variation is organizational. Baum (2010: 1507ff) outlines three features of immigration court that require judges to "adopt cognitive strategies that speed up the process of decision-making," which may lead to systematic differences in removal outcomes across geographies facing unique pressures. First, given the complexity of U.S. immigration law (Markowitz 2010), many judges hear cases that are "unusually difficult." Second, judges are under pressure to clear an over 714,000-case backlog in a timely fashion, and they must do so

\footnotetext{
${ }^{3}$ Before 1996, "exclusion" proceedings were held when the federal government sought to prevent noncitizens from entering the United States; "deportation" proceedings were reserved for those noncitizens who had already entered the country (see Legomsky and Rodríguez 2009). After IIRIRA in 1996, exclusion and deportation proceedings were combined into "removal" proceedings. In this article, I use "removal" and "deportation" interchangeably. ${ }^{4}$ All tabulations in this paragraph are author's calculations of Transactional Records Access Clearinghouse (TRAC). 2018. "Immigration Court Backlog Tool, Pending Cases and Length of Wait in Immigration Courts." $<$ https://bit.ly/2JLMD5E $>$.
} 
with limited assistance from law clerks and other support staff (Marks 2012). ${ }^{5}$ Finally, as administrators under the authority of the U.S. Attorney General, immigration judges are said to make decisions aligned not only with their own preferences but also those of their superiors - or otherwise judges risk removal from the bench (Legomsky 2005). If organizational features such as caseload and judicial norms vary across immigration courts, then these factors may also contribute to variation in removal outcomes.

A third potential source of variation relates to judges' personal attitudes, biases, and motivations. One stream of this research is set in asylum hearings. These studies foreground how judges' personal qualities - such as their gender or prior work experience (Schrag et al. 2009), policy predispositions (Keith et al. 2013), or attitudes toward specific national-origin groups (Rottman et al. 2009) - matter for asylum outcomes. Another research stream is set in bond determination hearings and uses noncitizens' case characteristics to proxy judges' decision-making processes. This scholarship finds that immigration judges are less likely to grant bail to detained noncitizens with criminal records (Ryo 2016), more likely to grant bond to detained noncitizens with attorney representation (Ryo forthcoming-b), and more likely to deem Central Americans and noncitizens without attorney representation as dangerous (Ryo forthcoming-a). Depending on the distribution of judges' personal attitudes, biases, or motivations, these conditions may explain variation not only between but also within immigration courts.

Scholars are accumulating evidence of the myriad factors associated with removal outcomes within and across U.S. immigration courts. But more can be learned about how immigration judges justify their decisions. In-depth data on judges' real-time decision-making —including but not limited to asylum and bond hearings - would improve our understanding of the social processes underlying removal outcomes. In addition, theorizing how immigration judges, key actors in the removal process, make decisions alongside the structural, organizational, and personal constraints they may perceive to their decision-making could shed light on how their decisions perpetuate the social control capacity of the federal immigration regime (see Rios et al. 2017: 500-501).

\section{Immigration Judges as Street-level Bureaucrats}

This article conceptualizes immigration judges as street-level bureaucrats, frontline workers who sometimes-unevenly interpret the law in order to enforce government policy while interfacing with the individuals subject to said policy (Lipsky 2010 [1980]; see Campbell 2012 for a review). The concept often conjures images of mid-level, white-collar workers such as teachers or social workers, but Lipsky's (2010 [1980]: p. 19-20) theory also encompasses relativelyempowered, higher-status professionals - including lower-court judges. ${ }^{6}$ Researchers have described street-level bureaucrats as rule-followers and -benders (see Heimer 2001 for a review). As rule-followers, they make routine, mechanistic decisions aligned with the laws governing the institutions of which they are a part (Emerson 1983; Gilboy 1991). As rule-benders, they exercise discretion beyond the formal laws or rules of the institution when encountering

\footnotetext{
${ }^{5}$ Source: Ibid. Figure current as of June 2018.

${ }^{6}$ Indeed, Lipsky (2010 [1980]: p. 20) offers lower-court judges as an example of street-level bureaucrats insofar as they have relative autonomy to exercise discretion but their decisions are subject to superiors' scrutiny. Lipsky also offers administrative law judges as street-level bureaucrats (p. 226).
} 
individuals they view as particularly "deserving" of assistance or opportunity (Dilulio 1994; Lempert 1989; Zacka 2017). Scholars have identified bureaucrats' dual roles as rule-followers or -benders in settings as diverse as pharmacies (Chiarello 2013), hospitals (Lara-Millán 2014), and welfare agencies (Watkins-Hayes 2009).

Conceptualizing immigration judges as street-level bureaucrats foregrounds their role as complex, creative actors situated within structural and bureaucratic contexts that enable and constrain - in an objective, legal sense and in a subjective, perceived sense - their discretionary authority. This conceptualization complements the emerging literature on judicial decisionmaking in immigration courts by acknowledging the potential for judges' personal attitudes, biases, and motivations to manifest as they carry out their work. It also extends this work by viewing immigration judges as actors who are enterprising in their decision-making - and who may sometimes exercise discretion in an attempt to circumvent structural and bureaucratic contexts they may view as constraining. As rule-followers or -benders, immigration judges make consequential decisions about whether to remove noncitizens from the country. Even when decisions result in the same outcome, how judges justify their decisions - by legitimating or contesting certain features of the federal immigration regime in open court - may shed light on these actors' roles in reproducing the social control of noncitizens. In sum, conceptualizing immigration judges as street-level bureaucrats facilitates analysis of the justifications these actors use to alleviate or worsen the conditions of the noncitizens who appear before them.

Research on court systems beyond the immigration context suggests how structural and bureaucratic features can condition judicial decision-making (Cohen 2009), and that greater scrutiny of judges' actions and interpretations can illuminate hidden pathways to social inequality (Stuart et al. 2015; see Lamont et al. 2014 on this broader point). For example, judges in criminal courts make decisions alongside other court officials such as prosecutors and defense attorneys (Eisenstein and Jacob 1977). Individual courts and even courtrooms can develop local organizational cultures, embedded within larger legal and political contexts, that differentially shape court officials' decisions (Eisenstein and Jacob 1977; Feeley 1979; Hagan and Peterson 2013; Johnson 2006). Judges are nevertheless relatively-autonomous actors. They are "strategic" in that their decisions take into account the preferences and actions of other officials (see Epstein and Jacobi 2010). But they also advance their personal interests - even amidst structural and organizational constraints - by framing their decisions as a declaration of what the law is (see Bybee 2012: 72). Recent work reveals how structural attempts to standardize criminal courtsfor example, through mandatory minimum sentencing — interact with judges' legal interpretations to reproduce racially-unequal sentencing outcomes (Clair and Winter 2016: 336).

My analysis follows this reasoning and examines in real time how immigration judges in Dallas Immigration Court justify their removal decisions. Despite their status as relatively-empowered actors in immigration court, the judges I observed largely described themselves as powerless to intervene on behalf of noncitizens. Yet, they sometimes exercised discretion in an apparent attempt to circumvent the removal process for those noncitizens they deemed as "deserving" of relief. As I outline below, understanding immigration judges as street-level bureaucrats helps to clarify some of the social processes underlying aggregate removal trends.

\section{STUDYING JUDICIAL DECISION-MAKING IN DALLAS IMMIGRATION COURT}




\section{Data and Analysis}

I rely on ethnographic data and informal conversations with immigration judges collected between June and August 2015 in Dallas Immigration Court, as well as archival materials relating to judges' roles as court administrators, to describe how judges in this setting justify their decisions. As of September 2016, 58 U.S. immigration courts operated. Table 1 compares features of Dallas Immigration Court to those of courts in Texas and nationwide in FY2015. A fraction of the country's 333,341 removals in this year were adjudicated in court (see Figure 1). Among all cases judges completed nationwide, about 41 percent ended in removal, compared with 57 percent in Texas and 66 percent in Dallas. Noncitizens in Dallas Immigration Court are less likely than noncitizens statewide and nationwide to have attorney representation, and they are more likely to be detained. Whether variation in removal patterns reflects judges' personal attitudes, organizational constraints, or the non-random distribution of cases across jurisdictions is unclear. ${ }^{7}$ Different dynamics may be at work in other immigration courts.

\section{[Table 1 about here.]}

I spent about 200 hours in Dallas Immigration Court, interacting with five judges, five DHS prosecutors, four courtroom interpreters, and four marshals, as well as dozens of family members and private attorneys of some noncitizens with cases before the court. Dallas had five sitting immigration judges at the time of the study - all male - and I divided time among each roughly equally. The first two days of fieldwork focused on proceedings with one immigration judge. My goal was to become a familiar, reliable presence in the courtroom. I did not write field notes until immediately following court. At the end of the second day of observations, the judge asked about my interest in the court. I began to explain that I was a graduate student at Harvard University at the time, and the judge interrupted excitedly to introduce me to the courtroom's Spanishlanguage interpreter - an alumna of Harvard College. The judge encouraged me to continue my observations and granted me permission to take notes during the proceedings. My university affiliation would facilitate access to the other four judges' courtrooms as well.

I produced over 150 single-spaced pages of field notes on Dallas Immigration Court. The judges made decisions regarding noncitizens in a range of legal situations, including but not limited to: cases involving unaccompanied minors, the undocumented parents of U.S.-citizen children, and noncitizens detained in two separate facilities. In this article, I focus on noncitizen adults, whose myriad cases the judges processed in similar enough ways to allow for an analysis of commonalities in judges' decision-making. Although DHS regulations precluded formal interviews, informal conversations with judges were documented in field notes (c.f. Gilboy 1991: 576). At the conclusion of each day's proceedings, judges answered my questions regarding the cases processed, including how they arrived at, and what they thought about, their decisions.

\section{[Table 2 about here.]}

\footnotetext{
${ }^{7}$ For example, some noncitizens may be apprehended in one, and then transferred to another, jurisdiction—either due to a court's bureaucratic constraints or because a noncitizen has requested the transfer. Nationwide, Benson and Wheeler (2012: 15) suggest that fewer than 27 percent of cases in 2011 were transferred to a different court or granted a change of venue.
} 
Table 2 summarizes the observed cases and outcomes, as well as several observable characteristics of the noncitizens with cases before the court during the fieldwork period. Proceedings ranged from initial master calendars (in which a noncitizen first appears in front of an immigration judge and can be ordered removed) to final individual merit hearings (in which a judge decides whether the noncitizen qualifies for relief). Most of the completed cases during the fieldwork ended in removal. Reflective of the protracted nature of removal proceedings, many cases are "right censored" in that I did not observe a judge's final decision on the case during the fieldwork period; the majority of observed cases were instead continued for another date. Among the observed noncitizens, most appeared to be male and most were detained. A plurality of the observed noncitizens designated Mexico as their home country. Fewer than half of the observed noncitizens with cases before the court during the fieldwork period had legal counsel, and most used an interpreter to communicate with the court.

Archival materials from Dallas Immigration Court, downloaded from the court's website in the summer of 2015, supplement the ethnographic fieldwork. They include documents from the Executive Office of Immigration Review (EOIR) instructing judges on how to advise noncitizens of their rights at the start of court proceedings and describing evidentiary standards in immigration court, as well as myriad templates for judges to complete during court proceedings. I use the archival materials to better understand judicial decision-making in immigration courts nationwide, to interpret the structural and bureaucratic contexts within which the court operates, and to examine what the law is on the books versus how it is applied on the ground.

I analyzed field notes and archival materials by reading them multiple times. After gaining a sense of the structural and bureaucratic contexts within which immigration judges exist, I inductively identified two approaches - scripted and extemporaneous - through which they justified their decisions. I re-read my data with these themes in mind, searching for confirmatory or disconfirming evidence of these categories. When words or sentences attributed to judges appear within quotations, these approximate exact quotations written either in real time or shortly thereafter. When words or sentences in the findings presented below are italicized, these data represent observations about which I wrote field notes several hours after court.

Though the observations reported here would have been publicly available to anyone studying Dallas Immigration Court, I do not identify specific judges. I came to this decision after having analyzed the data: This article finds that judges' shared interpretation of the federal immigration regime-encompassing "the law" or various aspects of the bureaucratic structure of which they are a part - as a constraint on their discretionary authority is primary in creating conditions that influence deportation decisions. Nevertheless, the distinct personal approaches, biases, or motivations that judges harbor are sometimes used to justify relief for noncitizens seen as "deserving" of relief. Attributions to individual judges would detract from a process-based model of decision-making (see Clair and Winter 2016; Eisenstein and Jacob 1977).

\section{Case}

Although the data and analysis focus on Dallas Immigration Court, removal proceedings in immigration courts nationwide share a similar structure. Figure 3 offers a stylized representation 
of removal proceedings. Archival documents outline the importance of this federal structure on judicial decision-making: At every step, immigration judges are to carry out removal proceedings in ways that ostensibly encourage a uniform application of U.S. immigration law.

[Figure 3 about here.]

The DHS initiates an action against a noncitizen the agency suspects is removable. The noncitizen is summoned to immigration court with a "Notice to Appear" (NTA), which delineates the accusations against them as well as the date they are to appear before the court. Once there, an initial master calendar hearing is held. Similar to an arraignment in the criminal court setting, initial master calendar hearings require immigration judges "to dispose of cases on that calendar that are susceptible to summary disposition and to ready the other cases for merits hearing and decision in one session of the individual calendar." ${ }^{\prime 8}$ Initial master calendars are designed to proceed relatively quickly, although as documents from the EOIR reveal, judges are also instructed to take time to learn about the particularities of each case: "It is... a plenary stage... at which, when little or no testimony is taken, the immigration judge has great flexibility to identify issues, make preliminary determinations of possible eligibility for relief, resolve uncontested matters, and schedule further hearings." These same documents outline the four key questions judges must answer of each noncitizen during the initial master calendar:

\begin{abstract}
...the inquiry with regard to any case can be simply stated as follows: Is the respondent an alien? If the respondent is an alien, is he or she deportable/removable/inadmissible on the charge or charges set forth in the notice to appear? If the respondent is deportable/removable/inadmissible, is there any provision of law which would allow the respondent to remain in the United States permanently? If there is nothing in the law which would allow the respondent to remain permanently in the United States, is the respondent going to be leaving the United States under order of removal and deportation or will the respondent be granted the privilege of voluntary departure at his or her own expense?
\end{abstract}

In some situations, a noncitizen has multiple master calendars or is moved to an individual merit hearing when the answers to these questions are not immediately apparent. Individual merit hearings allow more "complicated issues of deportability or removability or involved applications for relief which require a written application" to be adjudicated. Individual merit hearings are scheduled in 30-minute increments, with more time allocated "if there are complicated issues of law or fact" in a particular case. In this context, immigration judges consider evidence not only from the DHS prosecutor but also from the noncitizen-presented either through legal counsel or pro se. In Dallas, noncitizens whose cases were completed in FY2015 represented themselves about 63 percent of the time (see Table 1), tasked with providing testimony and evidence to demonstrate their own eligibility for relief.

Evidentiary standards in immigration court are in some ways less strict than those in criminal court. The EOIR reminds judges that, since removal proceedings are administrative, "adherence to judicial rules of evidence" is not ordinarily required "unless deviation would make the proceeding fundamentally unfair." 10 The evidence need only be lawfully obtained, have probative value, and be relevant to the case insofar as it makes "the existence of any fact that is

\footnotetext{
${ }^{8}$ Source: EOIR. nd. "The Master Calendar: Origin and Nature, Then and Now." On file with the author.

9 Ibid.

${ }^{10}$ Source: EOIR. nd. "Evidence Guide." On file with the author.
} 
of consequence to the determination of the action more probable or less probable than it would be without the evidence." In both master calendar and individual merit hearings, the DHS submits an I-213, a document that an arresting Customs and Border Protection (CBP) or Immigration and Customs Enforcement (ICE) official completes regarding a noncitizen's personal, criminal, and immigration record. The DHS was often the only party that presented evidence in support of their case in the removal proceedings observed during the fieldwork. ${ }^{11}$

At the conclusion of removal proceedings, a judge decides a noncitizen's case. Several outcomes are possible: (1) removal or deportation; (2) voluntary departure; ${ }^{12}$ (3) relief (e.g., asylum) or termination of the case (e.g., because the judge decides the government cannot sustain the charges it filed, the respondent establishes eligibility for naturalization, or the government agrees to the case's dismissal); or (4) administrative closure, which allows judges or DHS prosecutors to put cases "on hold." Among all completed cases in Dallas Immigration Court during FY2015, removal was the most common outcome (66 percent), followed by relief or termination (14 percent), administrative closure (10 percent), and voluntary departure ( 8 percent). The DHS and/or the noncitizen may appeal a judge's decision to the Board of Immigration Appeals (BIA). ${ }^{13}$ Noncitizens may appeal BIA decisions to the federal circuit court that covers the jurisdiction of the immigration court through which they were processed (Figure 2).

\section{FINDINGS}

\section{Deciding to Deport: Immigration Judges as Street-level Bureaucrats}

Conceptualizing immigration judges as street-level bureaucrats extends a growing body of research that demonstrates the social control capacity of the federal immigration regime in the United States. It does so by spotlighting how immigration judges may sometimes make routine decisions aligned with their beliefs about the constraint of "the law" and the larger bureaucratic structures of which they are a part. But it also reveals how judges' personal attitudes, biases, and motivations hypothesized in prior work (e.g., Keith et al. 2013; Rottman et al. 2009; Ryo 2016; Ryo forthcoming-a) can sometimes manifest in their decisions in ways that are flexible and creative - and in ways that are apparently intended to circumvent the removal process.

\section{Scripted Approach: Routine Removals in Dallas Immigration Court}

\footnotetext{
${ }^{11}$ Evidentiary guidelines during removal proceedings are not always straightforward. Immigration judges may not consider evidence presented during a bond determination hearing in a removal proceeding "unless...the evidence is reintroduced and received in the deportation or removal hearing." In contrast, judges may use evidence presented during bond determination hearings in the context of removal proceedings without reintroduction.

${ }^{12}$ See $\$ 240 B$ of the INA. In general, noncitizens are eligible for voluntary departure if they are not found to be deportable for having committed an aggravated felony or engaged in terrorist activities. Additional qualifications include a judge's determination that a noncitizen has been physically present in the country for a period of at least one year immediately preceding the date the NTA was served; that the noncitizen has been a person of good moral character for at least five years immediately preceding the application for voluntary departure; and that the noncitizen has established by clear and convincing evidence that they have the means and intention to depart the United States. Noncitizens granted a voluntary departure may be offered up to 120 days to depart the country at their own expense. Failure to comply converts the voluntary departure into a removal order.

${ }^{13}$ If a noncitizen is granted a voluntary departure and appeals the immigration judge's decision, the voluntary departure becomes a formal removal order until the appeal is adjudicated.
} 
The "scripted approach" to judicial decision-making in Dallas Immigration Court entails judges' recitation of well-rehearsed narratives regarding the limited legal rights and remedies available to noncitizens. This approach often occurred during initial master calendar hearings, where noncitizens who fall into easily-identifiable categories with clear legal outcomes-such as those who are undocumented and a recent entrant to the country, or those convicted of an aggravated felony - are processed. The judges used the scripted approach to justify, in a seeminglymechanistic fashion, the routine removal of noncitizens in most of the completed cases observed during the fieldwork.

The scripts judges follow when first encountering an individual noncitizen provide a template for the large-scale processing of noncitizens' cases. The judges began each removal proceeding I observed by reciting literal scripts from the EOIR to advise noncitizens of their rights. The judges then considered each case, one-by-one. Some noncitizens were physically present, whereas others were detained (as in Ryo 2016) and attended the hearing via video link (as in Eagly 2014). For each noncitizen appearing before the court for the first time, the judges asked if they would like a continuance to find an attorney. Noncitizens lack a constitutional right to courtappointed counsel during removal proceedings, though they are entitled to legal representation at no expense to the federal government (see Ryo forthcoming-b). Nationwide, 14 percent of detained, 25 percent of never-detained, and 41 percent of released noncitizens had at least one continuance between 2007 and 2012 (Eagly \& Shafer 2015: 33). My observations suggest that these low rates of representation may result from noncitizens' inability to afford a lawyer, rather than judges denying continuances altogether (although both explanations certainly may be true).

The judges in the study often offered the noncitizens before them at least one continuance to secure attorney representation before proceeding with their case. But the judges often balked at - and denied - requests for subsequent continuances. Given growing political pressure to clear an increasing backlog of cases, ${ }^{14}$ judges interpreted more than one continuance as either unnecessarily prolonging some noncitizens' detention or as a tactic for non-detained noncitizens to delay their removal indefinitely. For example, although a non-detained Honduran national I observed reported to one judge that he had used his first continuance to hire an attorney, he needed time to gather the funds required to pay the lawyer. The judge pressed the noncitizen for proof of contact in the form of the attorney's business card, which the noncitizen had available. Seemingly satisfied, the judge agreed to a second continuance of almost two months but warned sternly: "If you don't have an attorney by then, we will proceed without one."

When the question of attorney representation is settled - in most cases, with noncitizens unrepresented in Dallas Immigration Court (see Tables 1 and 2) - the judges proceeded with their scripts, seeking to categorize the noncitizens before them into legally-relevant categories. Reviewing the Notice to Appear and the submitted I-213 for each noncitizen, the majority of whom are undocumented, each noncitizen was asked the same set of questions, with only the details differing: "Are you a citizen of the United States? Are you a citizen of [country of origin]? Did you arrive to the United States through [place of entry] on [date]? Did you enter [legally/illegally] on said date? Is [country of origin] the country you want to go home to?"

\footnotetext{
${ }^{14}$ Rose (2018).
} 
These initial question-and-response exchanges seldom lasted longer than ten minutes during the proceedings I observed. Rather than reflecting any time pressure the judges communicated, the speed of this part of the hearing reflects the bureaucratic reality that, when a noncitizen first appears in immigration court, "There's just no opportunity for extenuating circumstances to be taken into account," as one DHS prosecutor told me. If the information before the judge suggests that a noncitizen is removable - for example, when a noncitizen is undocumented and a recent entrant to the country, or if they have been convicted of an aggravated felony-no relief is available under current U.S. immigration law. I witnessed a detained Honduran native convicted of an aggravated felony under the INA - cocaine possession-ordered deported. As the judge prepared to move to the next case on the docket, the noncitizen implored the judge in his Texasaccented English to consider his family ties: "I don't have nobody there [in Honduras]. I've been here for 15 years. My family doesn't even know I'm here [in removal proceedings]." The judge replied soberly, "I'm very sorry about that. But there's nothing I can do. Best of luck to you."

In the scripted approach, immigration judges' beliefs about noncitizens' preferred case outcomes help the judges to justify their decisions - even as they recognize that their decisions can appear mechanistic. Although judges process cases individually, each case forms part of a "stream of cases" that the judges handle (c.f. Emerson 1993: 426). This case stream provides a context for how the immigration judges I observed thought about the stakes of their removal decisions.

For example, four of the five judges described how they believed many noncitizens saw removal as a preferable outcome; instead of investing time and financial resources in an attorney while a judge adjudicated their case, noncitizens could invest time in attempting to re-enter the United States once deported. One prosecutor likened removal to a "get out of jail free" card, believing that anyone ordered deported would likely attempt to reenter the country shortly following their removal. One judge portrayed this phenomenon to me as "the elephant in the room that we never talk about," recounting a story about "Deportation Day" in his previous immigration court:
Sometimes we fly them into Mexico City [if they're from Mexico]. But that's too expensive to do for everyone, so more often than not, we bus them to the border. When I was a judge in [another immigration court], we sent deportees to Laredo, which was pretty far away from the immigration court. We called it Deportation Day or "Tuesday Taco Run" because this was when, after all the deportees got dropped off at the border, the CBP agents would put on their civilian clothing and go into Mexico to buy tequila, beer, tacos, and other cheap stuff best purchased in Mexico. When they went back stateside, a lot of the agents would run into some of the deportees they had just sent back home but who had already reentered the U.S. They would tell our agents, who couldn't do anything at that point, "Welcome to the U.S." It's just an anecdote but I've heard it several times from different people, so I believe it to be true.

Emerging from the ongoing processing of cases, court officials' beliefs that some noncitizens preferred an immediate order of removal to a protracted case adjudication is supported by the burgeoning research on this topic (see Hagan et al. 2008; Martínez et al. 2018). Instances of this apparent preference among noncitizens appeared to emerge during the fieldwork period. In one case, the DHS alleged that an unrepresented Mexican national had entered the country undocumented. The noncitizen objected that he had in fact overstayed his tourist visa. "If they're wrong [about your entering undocumented]," the judge advised, "then you can't be deported for that reason." The noncitizen nevertheless declined a continuance to search for his original visa and asked to be deported. The judge warned the noncitizen that removal could "negatively affect 
your chances of being able to reenter the country for a period of ten years;" ${ }^{15}$ the noncitizen acknowledged the possibility, and the judge ordered him removed. In another case, one judge determined that an undocumented immigrant from Mexico was eligible to have his removal canceled and to apply for legal permanent residence. The pro se noncitizen declined the opportunity, nodding in awareness that he would not be eligible to apply for this relief again.

In both the preceding cases, though attorney representation may have made the noncitizens more likely to seek and, be granted, relief (Eagly and Shafer 2015; see also Miller et al. 2014; Ryo forthcoming-a; Ryo forthcoming-b), ${ }^{16}$ the judges justified their removal orders as a larger "strategy" on the part of some of the noncitizens before them. As one judge summarized:

This strategy is most common among people from Mexico and Central America. For these people, it's better to be deported and come right back than be held up in jail. You know, these people have families depending on them. So, they ask themselves, "What's the point of applying for relief if I'm going to spend three or four months held up in jail and be unable to support my family with no guaranteed outcome?"

By following their scripts during initial master calendars, judges in Dallas Immigration Court processed the routine removals of noncitizens who fell into easily-identifiable categories with clear legal outcomes and who sometimes declined further investigation into their cases..

\section{Extemporaneous Approach: Deporting the "Deserving” from Dallas Immigration Court}

The "extemporaneous approach" to decision-making in immigration court entails judges" consideration of the circumstances surrounding noncitizens' cases - particularly when noncitizens' removability or eligibility for relief is not immediately apparent. This approach often occurred during subsequent master calendar or individual merit hearings. Through examination of noncitizens' extenuating circumstances, such as their ties to U.S. citizens or the context surrounding the commission of certain unlawful acts, judges move beyond their scripts and deliberate in greater depth about the cases before them. In the process, judges' personal attitudes, biases, and motivations are often revealed - with their resulting decisions sometimesunintentionally perpetuating the social control capacity of the federal immigration regime by leaving noncitizens in a precarious legal status that can jeopardize these individuals' future opportunities for legalization.

Greater judicial scrutiny of noncitizens' cases sometimes illustrates how current U.S. immigration law offers limited relief to noncitizens once apprehended or detained - no matter how "deserving" a judge believes them to be. One judge found a 26-year-old undocumented noncitizen from Mexico, convicted of driving while intoxicated, burglary, and evading arrest, to be removable - though not mandatorily so under the INA. The Deferred Action for Childhood Arrivals Program was one source of relief the judge thought might be available, but the noncitizen was ineligible because he never graduated from high school; the noncitizen reported

\footnotetext{
${ }^{15}$ A noncitizen with a removal order cannot reenter the United States legally for a period of ten years; if a noncitizen disobeys this order and reenters the country without authorization and is caught, in addition to serving a sentence in federal prison, they may be barred for 20 years or even indefinitely from applying for a visa or green card.

${ }^{16}$ This is not to suggest that immigration attorneys guarantee favorable outcomes. Indeed, I witnessed a number of instances in which apparently-unscrupulous immigration attorneys had charged their clients upwards of $\$ 5000$ for simple legal filings but failed to complete any of the tasks for which they were hired.
} 
having dropped out to provide financially for his undocumented mother and U.S.-born brother. The judge could not identify any other form of relief for the pro se undocumented noncitizen. ${ }^{17}$ "There's just no relief available to you," the judge concluded with apparent sympathy. "Not even if I get a lawyer?" the noncitizen replied in unaccented English. "I don't think so-you're not eligible for anything." The DHS prosecutor agreed: "The criminal issues are not stopping you. You just don't have any qualifying relatives [who can sponsor your legalization]." "Your honor, I don't have anybody there [in Mexico] and I'd be risking my life crossing the border," the undocumented noncitizen pleaded before being ordered removed. "Sir, I'm sorry," the judge replied. "If there were relief available, I'd offer it to you."

The judges in Dallas Immigration Court seemed aware of the limited pathways to relief available under current U.S. immigration law. In multiple cases, they expressed frustration when encountering noncitizens who were removable but who might have been able to avoid deportation under different circumstances. For example, a long-time legal permanent resident from Mexico - arrested but not convicted of a number of low-level drug offenses in June 2009sought to have his removal canceled and to naturalize via his U.S.-citizen wife. The noncitizen would first have to be pardoned for his criminal charges. But he fell four months shy of one of the requirements - five years of lawful admission after receiving his green card - to qualify. ${ }^{18}$ The judge continued to search for alternate forms of relief, inquiring as to whether the noncitizen's U.S.-born stepfather had ever legally adopted him. "This may be your only hope," the judge told the noncitizen. "If you were adopted by a U.S. citizen before the age of 16, and became a legal permanent resident by 18 , you become a citizen automatically. That means I wouldn't have any authority over you. I only have authority over noncitizens."

Though a petition was still on file with family court, the family's lawyer never finalized the adoption. The judge looked at me in exasperation, urging, "If you ever become a lawyer, make sure you're a good one." With no other relief available, the judge addressed the noncitizen: "Why didn't you naturalize?" "My mistake," he replied. "Yes, your mistake. [...] You wouldn't be here if you had naturalized. I'm not condoning your criminal activity, but you wouldn't have these immigration problems at least." The judge ordered the noncitizen, who was escorted out of the courtroom in shackles with two marshals, removed. The judge turned to me once they left and reflected: "It's unfortunate that he had to be deported because he probably doesn't know anyone in Mexico since he came to the U.S. at such a young age." The judge took this as "a lesson for the broader immigrant community that they should naturalize if they are eligible."

Against the backdrop of the limited relief available to many of the noncitizens before them, the judges in the study sometimes worked in an apparent attempt to circumvent the removal process for those they viewed as "deserving" of reprieve. One way they did so is through the legal mechanism of administrative closure, which allows immigration judges to remove a case from their calendar and delay a proceeding that could remove a noncitizen from the country. For

\footnotetext{
${ }^{17}$ Created in 2012, DACA is a discretionary status that grants a driver's license, work authorization, and reprieve from removal for eligible undocumented immigrants.

${ }^{18}$ Under the "stop time" rule, a noncitizen cannot gain any immigration benefits after committing a "crime of moral turpitude" within five years of their last admission to the United States, and if the offense carries a potential sentence of one year. See 8 USC $\S 1227$. The Board of Immigration Appeals (1988) defines a crime of moral turpitude as a behavior "that shocks the public conscience as being inherently base, vile, or depraved, contrary to the rules of morality and the duties owed between man and man, either one's fellow man or society in general."
} 
example, one undocumented Mexican national reappeared in court following a months-long continuance without an attorney. He explained to the judge that attorney representation was cost prohibitive for his family, narrating how he works full-time to pay for his terminally-ill wife's medical treatment as well as to care for their three U.S.-citizen children. The DHS prosecutor concluded that the noncitizen's criminal record did not make him an enforcement priority, and the prosecutor agreed to the judge's suggestion to close the case. "The government is making you a generous offer," the judge remarked. The judge explained, however, that administrative closure leaves the noncitizen in a precarious legal situation: "This doesn't give you legal status, work authorization, or a green card. Do you understand? It just means the government will not try to remove you right now." The noncitizen walked out of the courtroom, crying but visibly relieved. Given the May 2018 decision to ban administrative closure in immigration courts, it is uncertain at the time of this writing whether some of the more than 200,000 cases administratively closed between October 2011 and September 2017 will be reopened - and whether the noncitizens who have benefited from an administrative closure will be removed. ${ }^{19}$

Another apparent attempt at circumventing the removal process is through the legal mechanism of voluntary departure. Although eligibility requirements for voluntary departure are defined statutorily (see Footnote 12), some requirements are subject to a judge's interpretation — such as the perceived likelihood that a noncitizen will comply with the voluntary departure order. In one case, a non-detained male from El Salvador appeared pro se and admitted to having entered the United States unlawfully. He explained to the judge that his father died when he was six, and that he had immigrated to provide for his family. "So, you came here to improve your economic condition?" the judge clarified. The noncitizen responded: "I came here to study, learn English, and to do better in life." When asked whether there was a reason he could not return to El Salvador-ostensibly the judge's attempt to determine whether the noncitizen qualifies for relief, perhaps in the form of asylum - the noncitizen explained that he would "like an opportunity to stay [in the United States] because I don't have resources to study in El Salvador."

The judge listened intently to the noncitizen's statement before explaining how, despite his personal belief that the noncitizen is "noble," U.S. immigration law offers limited recourse for individuals in the noncitizen's situation:

I know you want to stay here, and I think it's very noble you want to help your family, but you have no reason to fear going home. There's no relief available to you. I don't get to choose to allow people to stay here because I want to. The law doesn't let me allow you to stay here.

The judge granted the noncitizen a voluntary departure, giving him four months to leave the country. The noncitizen walked freely out of the courtroom. Although not explicitly stated, the judge may have offered the noncitizen a voluntary departure as a way of enforcing the law while tacitly providing an opportunity for the "noble" noncitizen to remain in the country.

Judges' attempts at circumventing the removal process for "deserving" noncitizens are more explicit in other cases in the fieldwork period. For example, one Honduran national reported entering the United States undocumented with her four-year-old son in search of medical

\footnotetext{
${ }^{19}$ Benner, Katie. 2018. “Justice Dept. Restricts a Common Tactic of Immigration Judges.” New York Times. May 17. < https://nyti.ms/2k5nmVg>. Accessed online July 5, 2018.
} 
treatment for his convulsive syndrome. The woman appeared pro se and the judge guided her through a series of questions before determining that no relief was available for her to remain in the country: "Regrettably, based on what you've told me, you don't qualify for any relief the Court is aware of. You basically came here to get a job and help your son. While that's noble as a human being, it doesn't fall within statutory guidelines of the law." The judge granted the noncitizen a voluntary departure, encouraging her to turn in her paperwork to the U.S. consulate in Honduras so as to not forgo the possibility of reaping immigration benefits in the future.

When the noncitizen exited the courtroom, the judge turned to me and conceded that he did not believe the noncitizen would leave the United States voluntarily-despite the legal requirement that he factor this belief into his decision-making process before granting a voluntary departure:

She's not likely to comply because she's here to get medical treatment for her son. So she'll probably just stay in the U.S. and won't get picked up again because she doesn't look like the type to commit crimes.

She's well dressed, pretty, and has good manners. She may very well be able to live here just fine.

In this way, the judges in the study sometimes viewed voluntary departure and administrative closure as positive forms of "legal limbo" (see Menjívar 2006) they can offer "deserving" noncitizens while also abiding within the constraints of the federal immigration regime.

Although judges sometimes appeared to offer voluntary departure to eligible noncitizens they deemed "deserving" under the assumption that they might stay in the United States indefinitely, the consequences of noncitizens' non-compliance with voluntary departure can be negative and long-lasting. On the one hand, a voluntary departure converts into a removal order, preventing noncompliant noncitizens from accessing U.S. immigration benefits for a period of at least ten years. On the other hand, a record of non-compliance with immigration officials' decisions can compromise evaluations of noncitizens as moral, law-abiding individuals - an important quality in a federal immigration regime that valorizes the "good moral character" of noncitizens. ${ }^{20}$

The case of a pro se Mexican national I observed exemplifies the compounding effects of immigration officials' attempts at discretion for noncitizens' future legalization opportunities. One undocumented Mexican national sought a voluntary departure so that he might adjust his legal status in Mexico via his U.S.-citizen wife. But the judge had reason to believe that the noncitizen would not comply: DHS records revealed that CBP agents had previously returned the undocumented noncitizen to Mexico when he was caught entering the United States in 2009. But the noncitizen successfully entered shortly thereafter - a common pattern among Mexican migrants in an era of heightened border security (see Donato et al. 2008). With at least one voluntary return documented in the noncitizen's legal record, ${ }^{21}$ the judge interpreted the noncitizen's repeated clandestine border-crossings as evidence that the noncitizen "doesn't respect immigration law." The judge thus concluded that the noncitizen would not comply with the voluntary departure since he "didn't take advantage of voluntary return by not returning [to the United States]." The judge denied voluntary departure "as a matter of discretion" and ordered

\footnotetext{
${ }^{20}$ The INA defines good moral character as "character which measures up to the standards of average citizens of the community in which the applicant resides." See 8 CFR 316.10(a)(2).

${ }^{21} \mathrm{CBP}$ processes voluntary returns at a port of entry, usually for noncriminal cases. Individuals granted a voluntary return waive their rights to a formal hearing and agree to pay removal expenses. Statutorily, voluntary returns do not entail consequences for individuals seeking future lawful admission to the United States.
} 
the noncitizen removed to Mexico, making him ineligible for immigration benefits for a period of ten years - despite his potential current eligibility for relief via his U.S.-citizen wife.

This is not to say that immigration judges in Dallas always used voluntary departure as a form of discretionary relief for statutorily-eligible — and "deserving" — noncitizens. There were also instances in which the judges used voluntary departure in an apparently punitive manner, particularly for noncitizens they viewed as "deserving" but who visibly frustrated the judges for their seeming lack of willingness to take advantage of the opportunities the judges offered. For example, one Salvadoran national who appeared via video link from his detention center had been granted a continuance when he could not submit his cancellation of removal petition and application for legal permanent residence at his prior hearing. When he next appeared in court, the pro se noncitizen still had not submitted the petitions, explaining that he had difficulty gathering the required documents to complete the paperwork while detained. He requested another continuance, but the DHS prosecutor objected as "a matter of discretion." The judge sustained the objection, concluding that the noncitizen "abandoned his right to turn in his application to the court" after missing two submission deadlines. Despite the noncitizen's current eligibility and plea for more time to submit his legalization materials, the judge offered the noncitizen a voluntary departure so that he could "come back to the U.S. legally in the future."

By deviating from their scripts during subsequent master calendars or individual merit hearings, and deeming some noncitizens as "deserving" of reprieve, judges in Dallas Immigration Court perpetuate the social control capacity of the federal immigration regime. But what distinguishes a "deserving" from "undeserving" noncitizen? Some analyses point to immigration judges' reliance on noncitizens' individual or case characteristics, such as whether noncitizens have U.S.-citizen children (Mendelson 2010) or a felonious or violent criminal record (Ryo forthcoming-a). Observations in Dallas Immigration Court suggest that judges also make moral judgments about hard-to-quantify factors. As in other court contexts (see Clair and Winter 2016: 336), how immigration judges evaluate the "deservingness" of noncitizens depends on a collective process involving multiple actors - judges, prosecutors, attorneys, and/or clients. One actor's decisions can enable or constrain the range of choices available to other actors, with potentially-harmful effects on the outcomes of the noncitizens with cases before the judge.

The case of one noncitizen from El Salvador, who appeared in court from a detention facility several hours from Dallas to submit applications for cancellation of removal and legal permanent residence, illustrates this mutually-constitutive dynamic. The Salvadoran national had retained an attorney, a timid man who arrived to court early to ask the DHS prosecutor whether she would object to a continuance of the case to ensure that the noncitizen's application materials had been properly completed. The prosecutor nodded that she would object, adding that it was also unlikely the judge would grant another continuance since the noncitizen had been in detention for over six months (see Ryo 2016: 121-122). The immigration lawyer's worries about the completeness of his client's application materials were borne out almost immediately after the judge entered the courtroom and began considering the applications. The prosecutor objected to the materials' uncertified Spanish-to-English translations, which the judge sustained.

The attorneys in the courtroom took turns questioning the noncitizen. The noncitizen's lawyer, visibly shaken from the prosecutor's objections, went first. His questioning revealed how the 
noncitizen had been arrested at the hospital following a car accident for suspicion of driving while intoxicated. Through his lawyer, the noncitizen argued that his six-year-old, U.S.-citizen daughter would suffer if her father were removed because he would have to take her with him to a country she had never known. ${ }^{22}$ The DHS prosecutor then cross-examined the noncitizen, first asking questions that established that the noncitizen's child was healthy and doing well in school. The prosecutor then pointed to apparent inconsistencies on the noncitizen's application materials; for example, the noncitizen filed taxes as "head of household" in some years and "jointly" with his wife in others. The DHS prosecutor further noted how various sections of the cancellation and legalization petitions were incomplete. The noncitizen interjected to declare that he had given his attorney the information necessary to complete the application. "Why didn't you do it," the judge asked. The noncitizen, who relied entirely on an interpreter to communicate with the judge, replied solemnly in Spanish, "I thought my attorney did it."

Following the conclusion of questioning, the courtroom awaited the judge's oral decision. The judge's explanation of his decision reveals the moral judgments inherent in U.S. immigration law (e.g., Andrews 2017) that can lead judges to distinguish "deserving" from "undeserving" noncitizens: He found that the respondent was not a credible witness because of the inconsistencies between his testimony and the submitted application. Given this reported lack of credibility, the judge concluded that he could not take the noncitizen's word that he has lived in the country for at least ten years - a requirement for the relief for which he had applied. The judge further concluded that the noncitizen did not demonstrate good moral character because he filed his tax forms improperly in an alleged attempt to receive a higher tax break. With one driving while intoxicated charge pending, the judge viewed the noncitizen's "serious criminal record" as further evidence against his good moral character. The judge further noted that the noncitizen failed to demonstrate that his daughter would suffer "exceptional" hardship through her father's removal. The judge denied both petitions, rejected a request for voluntary departure because he did not believe the noncitizen would comply, and ordered the noncitizen removed.

\section{DISCUSSION AND CONCLUSION}

Through ethnographic observations of and informal conversations with judges in Dallas Immigration Court, as well as archival materials, this article describes two approaches through which judges in this setting justify their decisions. In the "scripted approach," the judges followed well-rehearsed narratives to recite the limited legal rights and remedies available to noncitizens. In the "extemporaneous approach," judges moved beyond their scripts to deliberate in greater depth about noncitizens' cases. In the process, judges' personal attitudes, biases, and motivations were often revealed, articulating their desire to circumvent the removal process for noncitizens they viewed as "deserving"- but who otherwise lacked full relief from removal given judges' interpretations of immigration law. These findings lend themselves to a framework of judicial decision-making in immigration court that conceptualizes judges as street-level

\footnotetext{
${ }^{22}$ Undocumented noncitizens who have lived in the United States for at least ten years may be eligible for legal permanent residence, particularly if their removal would cause "extreme hardship" to a U.S.-citizen or legal permanent resident spouse or child. Though not clearly defined in statute, USCIS outlines five categories of factors and considerations for extreme hardship: family ties and impact; social and cultural impact; economic impact; health conditions and care; and country conditions. See: USCIS Policy Manual, Vol. 9, Ch. 5. "Extreme Hardship Considerations and Factors.” <https://bit.ly/2emZcpa>. Accessed online July 5, 2018.
} 
bureaucrats, frontline workers who can interpret and apply the law unevenly. I argue, however, that even judges' relatively-rare attempts to circumvent removal for noncitizens they deemed to be deserving can amplify the social control capacity of the federal immigration regime.

Additional work is needed to further systematize immigration judges' roles as street-level bureaucrats. Ethnographic observations of, and informal conversations with, judges provide important insights into real-time decision-making; archival documents help to contextualize the structural and organizational conditions governing these decisions. In-depth interviews with immigration judges, within and across courts and federal jurisdictions, could refine or extend the findings offered here by allowing for a fuller exploration of the processes and contexts judges believe impact their decisions. Longer-term fieldwork could also be useful. Since the conclusion of the current study's fieldwork, one Dallas Immigration Court judge has transferred to another jurisdiction and two female judges have joined the formerly all-male court. Research suggests that judges' individual characteristics - such as gender - matter for court culture and norms (e.g., Schrag et al. 2009: 47-48; see also Keith et al. 2013). Sustained observations may help to illustrate how dynamism in structural and organizational conditions underlies removal outcomes. Future work should also pay attention to the decisions of judges on the Board of Immigration Appeals and in a number of federal circuit courts that hear appeals to Board decisions. The judges at these venues are though to have greater discretion than lower-court immigration judges (Baum 2010), and how their decision-making manifests requires scrutiny.

Although the fieldwork on which this study is based preceded the 2016 presidential election, there is reason to expect that the dynamics identified here will only become magnified going forward. First, the backlog of cases facing immigration judges has grown from more than 456,000 in FY2015 to more than 714,000 cases as of May 2018. ${ }^{23}$ About 15 percent of pending cases are set in Texas, and about 3 percent are set in Dallas. Second, the Executive Branch has placed added scrutiny on immigration judges to clear this backlog. U.S. Attorney General Jeff Sessions has directed immigration judges to clear at least 700 cases per year, and have fewer than 15 percent of their decisions overturned on appeal, or risk their place on the court. ${ }^{24}$ Finally, and coupled with research suggesting that immigration judges rely on cues to assess how "American" (Mendelson 2010) or "dangerous" (Ryo forthcoming-a) the noncitizens before them are, immigration judges may rely on these or additional cues to further identify noncitizens they view as "deserving" of relief — even when no full relief from removal might be available.

Conceptualizing immigration judges as street-level bureaucrats re-centers the primacy of the law as a real or perceived constraint on these actors' decision-making - without interpreting the law as deterministic. An emerging literature based on administrative or survey data uncovers important associations between immigration judges' personal characteristics, or noncitizens' case characteristics, and removal outcomes (e.g., Keith et al. 2013; Rottman et al. 2009; Ryo 2016; Schrag et al. 2009). Administrative categories such as "removal" or "voluntary departure" have legal meaning in that they imply that a noncitizen must leave the United States and dictate what immigration benefits are available to them. As the current study reveals, however, these categories also have hard-to-quantify social meanings: Like other judges (c.f. Bybee 2012: 81), immigration judges are embedded within contexts that they believe facilitate or limit their

\footnotetext{
${ }^{23}$ Source: TRAC (2018).

${ }^{24}$ Rose (2018).
} 
decisions. Ethnography permits analysis of judges' real-time decisions, and informal conversations with judges provide insights into the justifications these actors give for propagating or contesting the federal immigration regime when confronted with different noncitizens' cases. Combined with insights from administrative data, these multiple methods help to illuminate the often-hidden factors that reproduce the federal immigration regime.

In offering a framework of immigration judges as street-level bureaucrats, this article also demonstrates the value of studying the viewpoints of agents of the law-not only those of its targets. Ranging from Minutemen who patrol the Mexico-U.S. border (Shapira 2017 [2013]) to police agencies who cooperate with federal immigration officers (Armenta 2017), these actors contribute to social exclusion (Rios et al. 2017). Objective dimensions of exclusion encoded into immigration law are one part of this dynamic; the beliefs and actions of those who interpret and implement the law are another. In the context of Dallas Immigration Court, objective (e.g., a noncitizen's criminal record) and subjective factors (e.g., interpretations of who "deserves" to be deported) both shape removal outcomes. Conceptualizing immigration judges as street-level bureaucrats enables analysis of how structural and organizational contexts govern these actors' behavior while also revealing how judges' attitudes, biases, and motivations can operate to the detriment of the noncitizens before them. Studies of noncitizens' fears of removal illustrate how changes to the federal immigration regime since the mid-1980s have both expanded the conditions for deportation while also complicating noncitizens' ability to secure or maintain legal status (see National Academies of Sciences 2015). Federal immigration officials' perspectives should likewise be viewed as conditional on these macro-level contexts, with judges representing one set of actors whose perspectives on who does_-and does not_- "deserve" to be deported potentially aggregating to exacerbate removal rates.

Finally, this conceptualization amplifies the social control capacity of the federal immigration regime by revealing how even its agents' well-intentioned attempts at offering noncitizens relief can perpetuate removal outcomes. The finite forms of relief available to most noncitizens under U.S. immigration law sometimes visibly frustrated the judges I observed. In some cases, the judges offered forms of "relief," such as voluntary departure, to statutorily-eligible noncitizens in an apparent attempt to circumvent removal. As a legal matter, this form of relief would ostensibly allow a noncitizen to one day return to the United States with documentation. As a practical matter, however, the judges admitted that some noncitizens who accepted a voluntary departure were not likely to comply with it - particularly since many had families whose livelihoods depended on their durable presence in the United States. The current study suggests that the interaction between the structural and organizational realities of immigration court and judicial discretion can further exacerbate the subordination of noncitizens: In not complying with a voluntary departure, noncitizens are more likely to land in federal prison, to be viewed as "immoral" individuals who lack "good moral character" for not having complied with U.S. immigration law, and to be denied any opportunities for legalization that might become available for a period of at least ten years. If similar attempts at circumventing the removal process manifest in other immigration court jurisdictions, then a growing population of noncitizens may lack recourse for legalization going forward. The study thus amplifies the social control capacity of the federal immigration regime once a noncitizen has been apprehended or detained. 
Figure 1. All Removals and Court-ordered Removals of Noncitizens from the U.S., 1980-2015

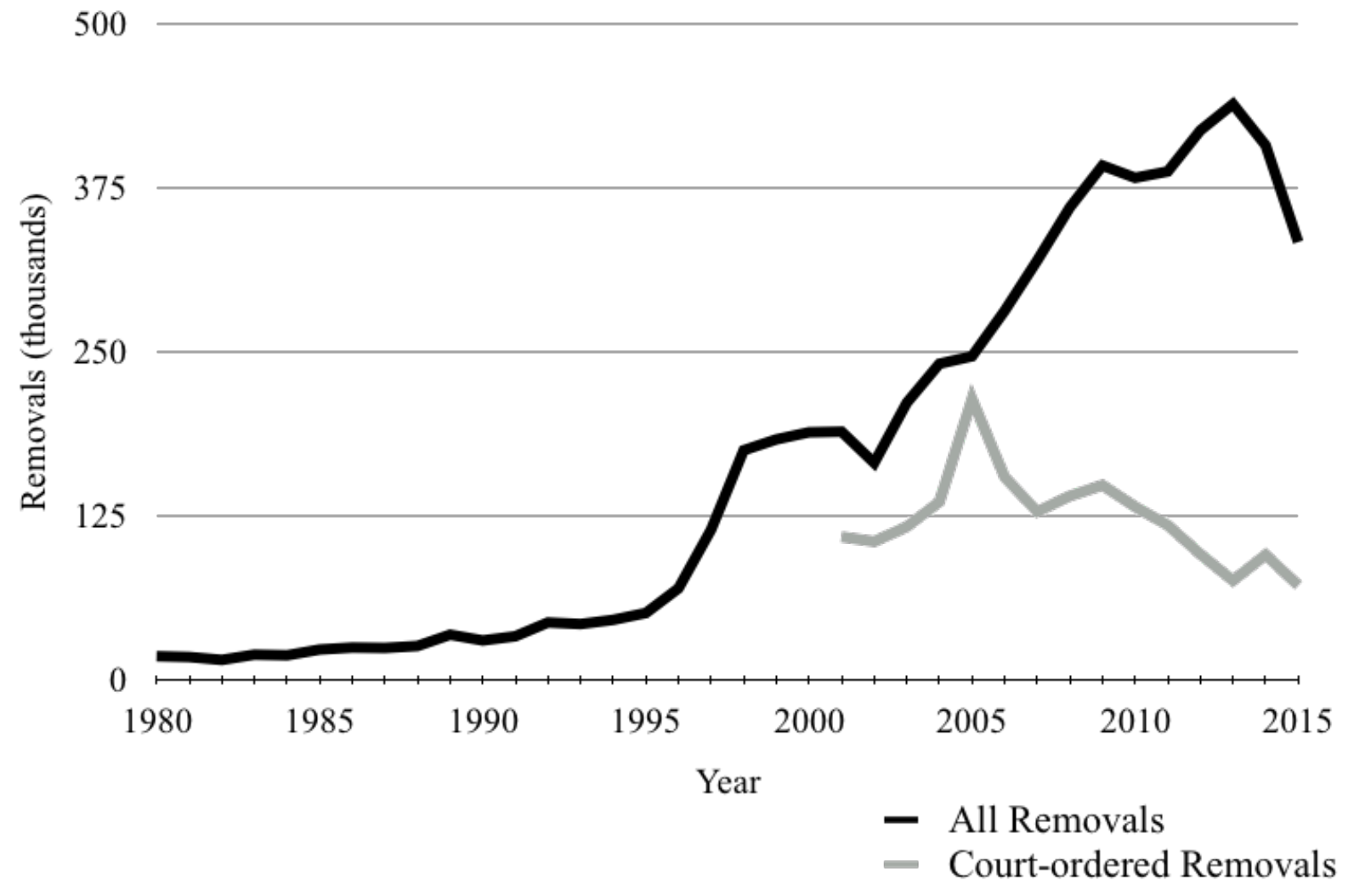

Source: Data on all removals from the United States are from Department of Homeland Security. 2016. "Table 39: Aliens Removed or Returned: Fiscal Years 1892 to 2015." Data on courtordered removals from the United States are from TRAC. 2018. "Details on Deportation Proceedings in Immigration Court." https://bit.ly/2GW5I0h. 
Figure 2. Stylization of U.S. Immigration Court Proceedings

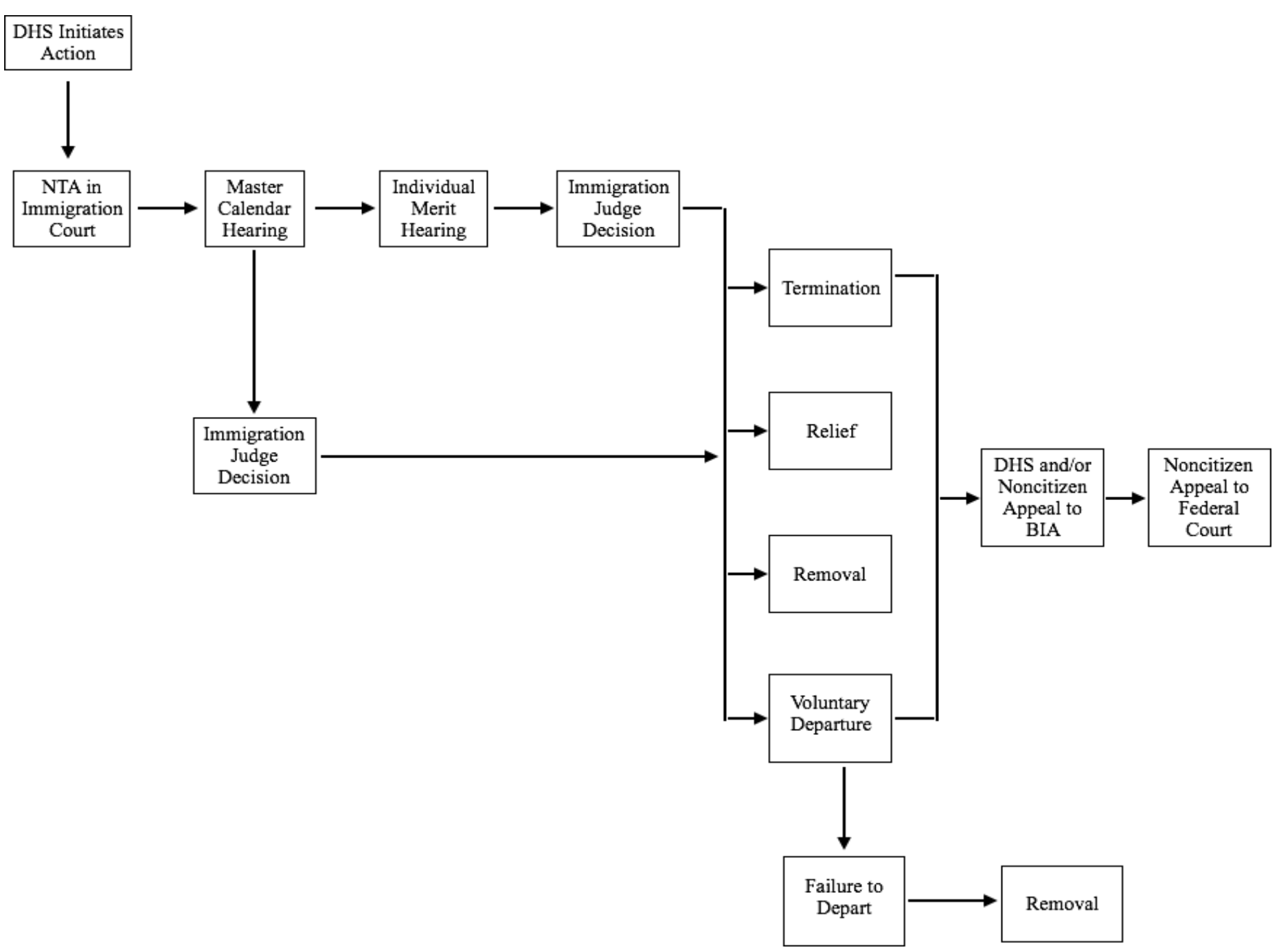


Figure 3. Federal Circuit Court Districts in the United States

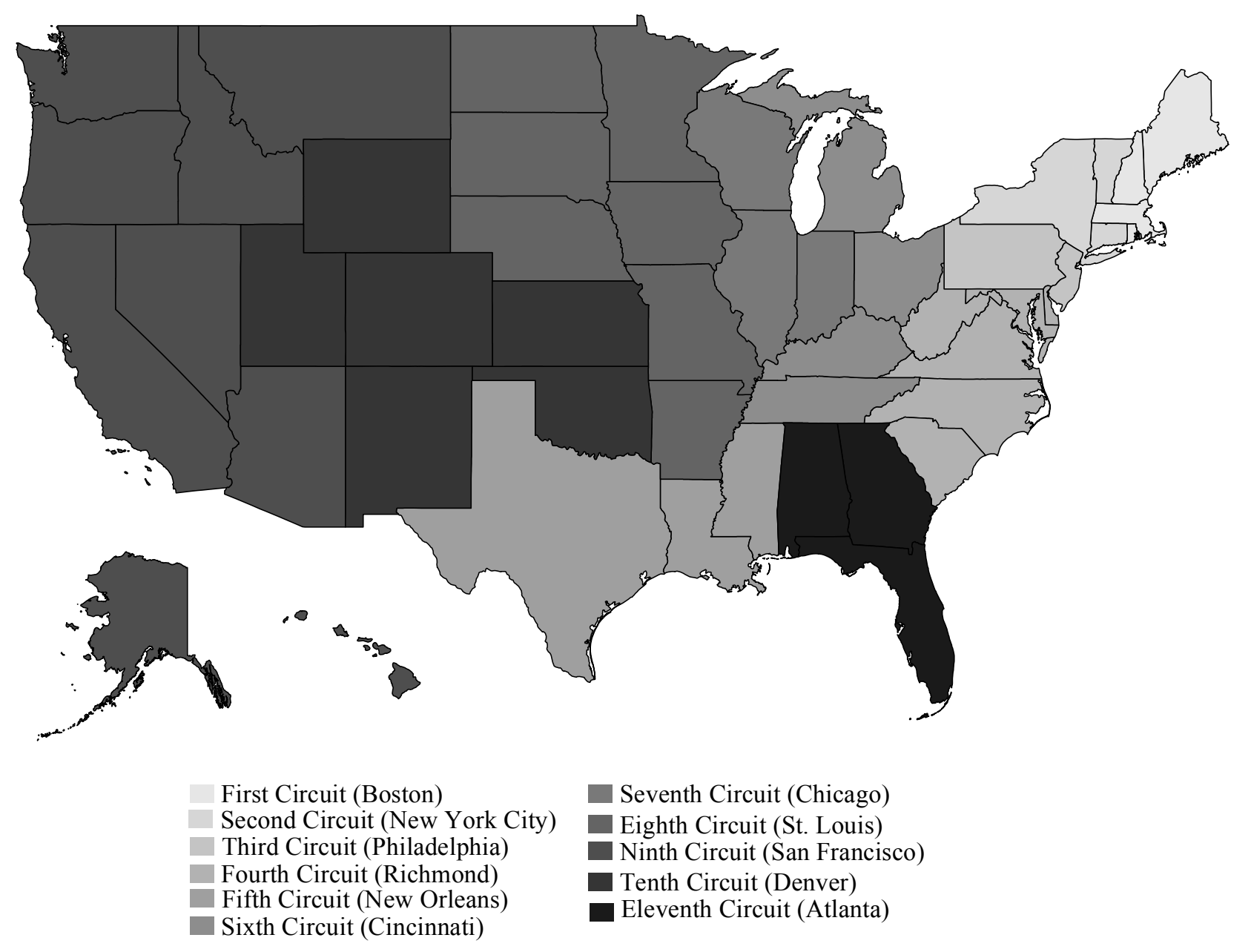


Table 1. Comparison of Matters Completed by Immigration Judges in Dallas Immigration Texas Immigration Courts, and Nationwide Immigration Courts, FY2015

\begin{tabular}{|c|c|c|c|}
\hline & Dallas & Texas & Nation \\
\hline Number of Judges (N) & 5 & 31 & 247 \\
\hline Completed Cases $(\mathrm{N})$ & 9,492 & 35,833 & 199,3 \\
\hline Concluded with Removal Order (\%) & 65.8 & 56.5 & 41.' \\
\hline Concluded with Voluntary Departure (\%) & 7.53 & 5.18 & 5.21 \\
\hline Concluded with Terminations $(\%)$ & 10.9 & 9.32 & 14. \\
\hline Concluded with Relief Granted (\%) & 2.25 & 4.72 & 10. \\
\hline Concluded with Administrative/Other Closure (\%) & 9.84 & 14.2 & 24. \\
\hline Conducted with Attorney Representation (\%) & 35.6 & 43.9 & 63. \\
\hline Conducted as Detained Proceedings (\%) & 47.4 & 35.8 & 21. \\
\hline Average Days to Completion & 435 & 236 & 816 \\
\hline \multicolumn{4}{|c|}{$\begin{array}{l}\text { Source: Author's tabulations of TRAC. 2018. "Immigration Court Backlog Tool, Pending Cases and Length } \\
\text { in Immigration Courts." https://bit.ly/2JLMD5E. } \\
\text { Notes: Number of judges in Dallas accurate as of June 2015. Number of judges in Texas and nationwide acc } \\
\text { of June } 2015 \text {. Completed cases represent Fiscal Year 2015. Data on cases conducted with attorney represent } \\
\text { and as detained proceedings in Dallas are author's tabulations of TRAC (2018), based on "current status" of }\end{array}$} \\
\hline
\end{tabular}


Table 2. Summary of Cases, Outcomes, and Noncitizens Observed in Dallas Immigration Court $\left(\mathrm{N}_{\text {Cases }}=283 ; \mathrm{N}_{\text {Outcomes }}=283 ; \mathrm{N}_{\text {Noncitizens }}=263\right)$

\begin{tabular}{|c|c|}
\hline & $\%$ \\
\hline \multicolumn{2}{|c|}{ Cases Observed, by Type $(\mathrm{N}=283)^{\mathrm{a}}$} \\
\hline Master Calendar & 84.5 \\
\hline Individual Merit Hearing & 8.5 \\
\hline Bond Hearing & 7.1 \\
\hline \multicolumn{2}{|l|}{ Observed Outcomes $(\mathrm{N}=283)$} \\
\hline Ordered Removed & 32.2 \\
\hline Voluntary Departure & 5.3 \\
\hline Termination/Closure & 6.4 \\
\hline Bond & 2.8 \\
\hline Continuance & 53.4 \\
\hline \multicolumn{2}{|c|}{ Observable Characteristics of Noncitizens $(\mathrm{N}=263)^{\mathrm{b}}$} \\
\hline Male & 75.7 \\
\hline Detained & 75.3 \\
\hline \multicolumn{2}{|l|}{ National Origin ${ }^{c}$} \\
\hline Mexican & 38.4 \\
\hline Other & 62.6 \\
\hline Represented by Attorney & 44.9 \\
\hline Used Courtroom Interpreter & 76.0 \\
\hline \multirow{2}{*}{\multicolumn{2}{|c|}{$\begin{array}{l}\text { Source: Author's tabulations of ethnographic field notes. } \\
\text { Notes: }\end{array}$}} \\
\hline & \\
\hline \multicolumn{2}{|c|}{$\begin{array}{l}\text { a Tabulations do not include observed cases that involved minors or cases where a noncitizen did not appear at the } \\
\text { hearing. In the latter case, judges automatically ordered "no shows" removed. }\end{array}$} \\
\hline \multicolumn{2}{|c|}{$\begin{array}{l}\text { ' Observed bond hearings often occurred immediately following a noncitizen's master calendar hearing. To avoid } \\
\text { double-counting noncitizens' observable demographics, I exclude bond hearings and focus on noncitizens in master } \\
\text { calendar and individual merit hearings. }\end{array}$} \\
\hline \multicolumn{2}{|c|}{$\begin{array}{l}{ }^{\mathrm{c}} \text { Nationalities of noncitizens observed in immigration court other than Mexicans include Salvadorans, Hondurans, } \\
\text { Panamanians, Bolivians, Chinese, Nepalese, Burmese, Peruvian, Cuban, Turkish, and Eritrean, among others. }\end{array}$} \\
\hline
\end{tabular}




\section{References}

Andrews, Abigail L. 2017. "Moralizing Regulation: The Implications of Policing "Good” Versus "Bad" Immigrants." Ethnic and racial studies:1-19.

Appeals, Board of Immigration. 1988. "Matter of Danesh." Board of Immigration Appeals Decision \#3068.

Armenta, Amada. 2017. "Protect, Serve, and Deport: The Rise of Policing as Immigration Enforcement."

Asad, Asad L. 2017. "Reconsidering Immigrant Illegality: How Immigrants Perceive the Risk of Immigration Law and Enforcement." Department of Sociology, Harvard University, Cambridge, MA.

Asad, Asad L and Matthew Clair. 2018. "Racialized Legal Status as a Social Determinant of Health." Social Science \& Medicine 199:19-28.

Baum, Lawrence. 2010. "Fortieth Annual Administrative Law Symposium: Judicial Specialization and the Adjudication of Immigration Cases." Duke Law Journal:1501-61.

Benson, Lenni B and Russell R Wheeler. 2012. "Enhancing Quality and Timeliness in Immigration Removal Adjudication." in Washington, DC: Administrative Conference of the US.

Bybee, Keith J. 2012. "Paying Attention to What Judges Say: New Directions in the Study of Judicial Decision Making." Annual Review of Law and Social Science 8:69-84.

Campbell, Andrea Louise. 2012. "Policy Makes Mass Politics." Annual Review of Political Science 15:333-51.

Chacón, Jennifer M. 2010. "A Diversion of Attention? Immigration Courts and the Adjudication of Fourth and Fifth Amendment Rights." Duke Law Journal:1563-633.

Chiarello, Elizabeth. 2013. "How Organizational Context Affects Bioethical Decision-Making: Pharmacists' Management of Gatekeeping Processes in Retail and Hospital Settings." Social Science \& Medicine 98:319-29.

Clair, Matthew and Alix S Winter. 2016. "How Judges Think About Racial Disparities: Situational Decision-Making in the Criminal Justice System." Criminology 54(2):332-59.

Cohen, Jonathan M. 2009. Inside Appellate Courts: The Impact of Court Organization on Judicial Decision Making in the United States Courts of Appeals: University of Michigan Press.

Council, American Immigration. 2014. "Removal without Recourse: The Growth of Summary Deportations from the United States." Vol. Washington, D.C.: American Immigration Council.

Dilulio, John D. 1994. "Principled Agents: The Cultural Bases of Behavior in a Federal Government Bureaucracy." Journal of Public Administration Research and Theory 4(3):277-318.

Dingeman-Cerda, Katie. 2017. "Segmented Re/Integration: Divergent Post-Deportation Trajectories in El Salvador." Social problems.

Donato, Katharine M, Brandon Wagner and Evelyn Patterson. 2008. "The Cat and Mouse Game at the Mexico-Us Border: Gendered Patterns and Recent Shifts." International Migration Review 42(2):330-59.

Eagly, Ingrid V. 2014. "Remote Adjudication in Immigration." Nw. UL Rev. 109:933. Eagly, Ingrid V and Steven Shafer. 2015. "A National Study of Access to Counsel in Immigration Court." U. Pa. L. Rev. 164:1. 
Eisenstein, James and Herbert Jacob. 1977. Felony Justice: An Organizational Analysis of Criminal Courts: Little, Brown Boston.

Emerson, Robert M. 1983. "Holistic Effects in Social Control Decision-Making." Law and Society Review:425-55.

Epstein, Lee and Tonja Jacobi. 2010. "The Strategic Analysis of Judicial Decisions." Annual Review of Law and Social Science 6:341-58.

Feeley, Malcolm M. 1979. The Process Is the Punishment: Handling Cases in a Lower Criminal Court: Russell Sage Foundation.

Fine, Lisa R. 1997. "Preventing Miscarriages of Justice: Reinstating the Use of Judicial Recommendations against Deportation." Geo. Immigr. LJ 12:491.

García Hernández, César Cuauhtémoc. 2014. "Immigration Detention as Punishment." Immigr. \& Nat'lity L. Rev. 35:385.

Gilboy, Janet A. 1991. "Deciding Who Gets In: Decisionmaking by Immigration Inspectors." Law and Society Review:571-99.

Golash-Boza, Tanya. 2013. "From Legal to 'Illegal': The Deportation of Legal Permanent Residents Form the United States." Pp. 203-22 in Constructing Immigrant 'Illegality': Critiques, Experiences, and Responses, edited by C. Menjívar and D. Kanstroom. Cambridge: Cambridge University Press.

Hagan, Jacqueline, Karl Eschbach and Nestor Rodriguez. 2008. "Us Deportation Policy, Family Separation, and Circular Migration." International Migration Review 42(1):64-88.

Hagan, John and Ruth D Peterson. 2013. "Changing Conceptions of Race: Toward an Account of Anomalous Findings of Sentencing Research." Pp. 69-86 in Race, Crime, and Justice: Routledge.

Heimer, Carol A. 2001. "Cases and Biographies: An Essay on Routinization and the Nature of Comparison." Annual Review of Sociology 27(1):47-76.

Johnson, Brian D. 2006. "The Multilevel Context of Criminal Sentencing: Integrating Judge-and County-Level Influences." Criminology 44(2):259-98.

Kanstroom, Daniel. 2007. Deportation Nation: Outsiders in American History: Harvard University Press.

Keith, Linda Camp, Jennifer S Holmes and Banks P Miller. 2013. "Explaining the Divergence in Asylum Grant Rates among Immigration Judges: An Attitudinal and Cognitive Approach." Law \& Policy 35(4):261-89.

Koh, Jennifer Lee. 2012. "Waiving Due Process (Goodbye): Stipulated Orders of Removal and the Crisis in Immigration Adjudication." NCL Rev. 91:475.

Lamont, Michèle, Stefan Beljean and Matthew Clair. 2014. "What Is Missing? Cultural Processes and Causal Pathways to Inequality." Socio-Economic Review 12(3):573-608.

Lara-Millán, Armando. 2014. "Public Emergency Room Overcrowding in the Era of Mass Imprisonment." American Sociological Review 79(5):866-87.

Legomsky, Stephen H. 2005. "Deportation and the War on Independence." Cornell L. Rev. 91:369.

Lempert, Richard. 1989. "Discretion in a Behavioral Perspective: The Case of a Public Housing Eviction Board."

Lipsky, Michael. 2010 [1980]. Street-Level Bureaucracy: Dilemmas of the Individual in Public Service: Russell Sage Foundation.

Lustig, Stuart L, Sarah Kureshi, Kevin L Delucchi, Vincent Iacopino and Samantha C Morse. 2008. "Asylum Grant Rates Following Medical Evaluations of Maltreatment among 
Political Asylum Applicants in the United States." Journal of immigrant and minority health 10(1):7-15.

Markowitz, Peter L. 2010. "Deportation Is Different." U. Pa. J. Const. L. 13:1299.

Marks, Dana Leigh. 2012. "Still a Legal Cinderella-Why the Immigration Courts Remain an Ill Treated Stepchild Today." Fed. Law. 59:25.

Martínez, Daniel E, Jeremy Slack and Ricardo D Martínez-Schuldt. 2018. "Repeat Migration in the Age of the "Unauthorized Permanent Resident" a Quantitative Assessment of Migration Intentions Postdeportation." International Migration Review:0197918318767921.

Mendelson, Margot K. 2010. "Constructing America: Mythmaking in Us Immigration Courts." The Yale law journal:1012-58.

Menjívar, Cecilia. 2006. "Liminal Legality: Salvadoran and Guatemalan Immigrants' Lives in the United States." American journal of sociology 111(4):999-1037.

Menjívar, Cecilia, Leisy J Abrego and Leah C Schmalzbauer. 2016. "Immigrant Families." John Wiley \& Sons.

Miller, Banks, Linda Camp Keith and Jennifer S Holmes. 2014. Immigration Judges and Us Asylum Policy: University of Pennsylvania Press.

Moinester, Margot. 2018. "Beyond the Border and into the Heartland: Spatial Patterning of Us Immigration Detention." Demography:1-47.

National Academies of Sciences, Engineering, and Medicine. 2015. "The Integration of Immigrants into American Society." Vol. Panel on the Integration of Immigrants into American Society. Cambridge, MA: National Academies of Sciences, Engineering, and Medicine.

Rios, Victor M, Nikita Carney and Jasmine Kelekay. 2017. "Ethnographies of Race, Crime, and Justice: Toward a Sociological Double-Consciousness." Annual Review of Sociology 43:493-513.

Rottman, Andy J, Christopher J Fariss and Steven C Poe. 2009. "The Path to Asylum in the Us and the Determinants for Who Gets in and Why." International Migration Review 43(1):3-34.

Ryo, Emily. 2016. "Detained: A Study of Immigration Bond Hearings." Law \& Society Review 50(1):117-53.

Ryo, Emily. forthcoming-a. "Predicting Danger in Immigration Courts." Law \& social inquiry.

Ryo, Emily. forthcoming-b. "Representing Immigrants: The Role of Lawyers in Immigration Bond Hearings." Law \& Society Review.

Schrag, Philip G, Andrew I Schoenholtz and Jaya Ramji-Nogales. 2009. Refugee Roulette: Disparities in Asylum Adjudication and Proposals for Reform: NYU Press.

Shapira, Harel. 2017 [2013]. Waiting for José: The Minutemen's Pursuit of America: Princeton University Press.

Stuart, Forrest, Amada Armenta and Melissa Osborne. 2015. "Legal Control of Marginal Groups." Annual Review of Law and Social Science 11(1).

Stumpf, Juliet P. 2006. "The Crimmigration Crisis: Immigrants, Crime, and Sovereign Power." American University Law Review 56:367.

Watkins-Hayes, Celeste. 2009. The New Welfare Bureaucrats: Entanglements of Race, Class, and Policy Reform: University of Chicago Press.

Zacka, Bernardo. 2017. When the State Meets the Street: Public Service and Moral Agency: Harvard University Press. 